\title{
A IMPROVISAÇÃO NA CONCEPÇÃO DE PROGRAMAS SOCIAIS muitas convicções, poucas constatações o caso do primeiro emprego
}

Felícia Reicher Madeira

\begin{abstract}
Resumo: $\mathrm{O}$ artigo apresenta proposta de avaliação de políticas públicas sociais diferente das convencionais - que enfocam os resultados dos impactos -, propondo nova conduta, mais próxima das ciências sociais e priorizando a análise dos fatos e processos definidores do desenho e do desenvolvimento do programa, o que permite evidenciar os equívocos de formulação. Para tanto, avalia o Programa Jovem Cidadão: Meu Primeiro Trabalho e sugere ampliação de pesquisas sociais comparadas. Palavras-chave: avaliação de políticas públicas; políticas sociais; programas sociais.

Abstract: This article presents a proposal of evaluation of the social public politics different from the conventional - that focuses on the results of the impacts -, proposing new conduct, closer to the social sciences and prioritizing the analyses of facts and defining processes of the creation and the development of the program that allows the evidence of formulation mistakes. Thus, it evaluates the Young Citizen Program: My First Employment and suggests enlargement of comparative social research. Key words: evaluation of public politics; social politics; social programs.
\end{abstract}

$\mathrm{E}$ ste artigo concentra-se em dois temas que interagem profundamente. Desde logo, procura-se chamar a atenção para o fato de que grande parte do fracasso recorrente dos programas sociais de natureza focalizada decorre dos mesmos estarem, com freqüência, operando na lógica de responder a pressões de urgências cotidianas, ancoradas no voluntarismo, na intuição, em convicções que ouvem mais o coração do que a mente. De fato, numa espécie de círculo vicioso, também porque ainda não encontraram espaço na mídia, várias ações sociais públicas continuam marcadas pela improvisação e pelo amadorismo. Por não apresentarem referências teóricas mais sólidas, escorregam facilmente para politização e ideologização. O grave é que, para algumas delas, já existe vasta, profunda e antiga avaliação e reflexão, anunciando seu fracasso, bem como a possibilidade de seu efeito ser perverso, um verdadeiro tiro no pé.

Para enfrentar esta situação, o primeiro passo é levar a questão a debate público. Entretanto, para que isto ocorra, é fundamental ampliar a ótica que orienta, monitora e avalia as ações sociais. Durante os anos 90 , foi grande e crescente a ocupação dos espaços de avaliação das ações públicas pelos economistas, realizando a reflexão e utili- zando as ferramentas do chamado maistream. Trata-se, sem dúvida, de contribuições importantíssimas e também utilizadas neste trabalho, entretanto, a intenção aqui é colaborar para compreender melhor o processo decisório, o desenho e o funcionamento das políticas sociais da ótica das Ciências.

$\mathrm{Na}$ verdade, este artigo concorda e se inspira em Faria (2002:76), quando o autor sugere que as "avaliações são indispensáveis para o bom funcionamento das políticas (...) Porque sem essas avaliações, sem uma discussão mais densa a respeito das políticas, o debate público fica totalmente prejudicado. Para melhorar a qualidade do debate público, parece-me absolutamente indispensável, fundamental, a contribuição das ciências sociais, não apenas do ponto de vista de tocar nas nossas mazelas, mas também do ponto de vista de chamar a atenção para dificuldades, constrangimentos, problemas, políticas imaginadas como extremamente eficientes e eficazes, mas que na realidade, se bem analisadas, demonstram não ter impacto tão grande sobre a desigualdade".

A improvisação voluntarista está presente nas mais diferentes ações de combate às desigualdades sociais, mas aparece especialmente forte quando o tema é o enfrentamen- 
to das elevadas e persistentes taxas de desemprego juvenil. Por este motivo, o artigo toma como referência o Programa Jovem Cidadão: Meu Primeiro Trabalho (PJC), cujo objetivo era oferecer, por seis meses, com apoio de subsídios do Estado, estágios na iniciativa privada e em ONGs, para 270.000 jovens que cursavam o ensino médio nas escolas públicas da Região Metropolitana de São Paulo. À medida que o núcleo central do argumento deste texto é atentar para a falta de critério técnico científico na concepção dos programas sociais do setor público, o artigo está estruturado de forma a contrapor pressupostos que orientaram o PJC e que são repetidos em todos os programas desta natureza (por exemplo, o Programa Primeiro Emprego do atual governo federal), com resultados de experiências e avaliações internacionais, além do conhecimento já acumulado das experiências recentes e daquelas em andamento. Ambas, como argumentamos, fornecem boas pistas para as correções de rumo de programas desta natureza.

$\mathrm{O}$ artigo advoga também a necessidade urgente de aprofundar pesquisas e análises na área de mercado de trabalho. Está organizado em quatro tópicos, além desta introdução. O primeiro aborda a mídia e o foco do público-alvo, discutindo o contexto em que o Programa Jovem Cidadão foi gerado. O segundo detalha o diagnóstico e o desenho do Programa. O terceiro discorre sobre os principais equívocos cometidos na concepção do Programa, chamando a atenção para o fato de que políticas como esta, pensadas como eficientes e eficazes, às vezes não têm grande impacto sobre o problema que se quer minimizar. O quarto, como conclusão, destaca as lições aprendidas e sugere que elas sejam discutidas e aperfeiçoadas em favor da causa jovem.

\section{A MÍDIA E O FOCO DO PÚBLICO-ALVO}

Desde meados dos anos 50, entre $30 \%$ e $40 \%$ da população brasileira vive em famílias pobres (em 2002, representava $33 \%$ ). ${ }^{1}$ A persistência da pobreza não decorre da falta de recursos dirigidos a programas sociais, pois o Brasil gasta, anualmente, aproximadamente $20 \%$ do PIB nesta rubrica, quase dois terços das receitas do governo, que equivalem a $34 \%$ do PIB.

Qual então a razão deste aparente paradoxo? O principal motivo é que os gastos sociais estão maldirecionados - concentram-se majoritariamente nos 30\% a $40 \%$ menos pobres da população. Por esta razão, a questão da focalização das políticas sociais - do acerto dos gastos sociais - tem ganhado destaque no debate atual. O tema da focalização é, em última instância, o da racionalização dos escassos recursos disponíveis.

Diante da importância do tema na nova agenda de políticas sociais, uma primeira questão a ser colocada é: o PJC contribui para minimizar as desigualdades sociais e seus desdobramentos atuais e futuros? A resposta, cujos argumentos serão aqui desenvolvidos, é não. Então, vale a pena indagar, por que afinal se elegeu este foco de atuação? Por que tanto empenho neste Programa? As respostas a estas questões levam a refletir sobre um problema que se repete: o fato de os processos de tomada de decisão sobre prioridades da ação pública social ocorrerem sobre a pressão de circunstâncias, de grupos de interesse, sem observar prioridades e focos.

Segundo o Censo Demográfico de 2000, época em que o Programa foi estruturado, residiam na Região Metropolitana de São Paulo (RMSP) 48.922 jovens analfabetos entre 15 e 24 anos e 1.057 .726 que não completaram o ensino fundamental (oito anos). Destes últimos, $47 \%$ estão na faixa etária de 20 a 24 anos. Ainda no grupo de idade de 20 a 24 anos, $85,3 \%$ não concluíram ou nem freqüentaram o ensino médio. Quase 32\% dos jovens entre 15 e 24 anos eram inativos e, destes, 11,6\% estavam fora da escola. Nada menos do que 7,5\% eram homens chefes de família e 2,2\% das mulheres já eram mães e chefes de família. A trajetória destes jovens não oferece muitas alternativas: sem completar o ensino fundamental, ou mesmo o médio, dificilmente encontrarão empregos decentes e serão as famílias pobres de amanhã. A escolaridade da mãe, como se sabe, é decisiva para o bom aproveitamento escolar das crianças, assim como os cuidados preventivos com a saúde. Sem a eliminação destes problemas, a reprodução da miséria é certa.

Por que, então, tanto empenho em um programa de geração de trabalho centrado nos jovens que estão cursando o ensino médio? A explicação desta "escolha" está no cenário paulista do final dos anos 90 . Era o início do segundo mandato do governador Covas e havia a recorrência de casos de violência envolvendo a comunidade escolar, inclusive no interior de escolas. Tais acontecimentos tiveram grande repercussão na mídia, aprofundando o pânico e a angústia já presentes na sociedade. A sensação que envolvia o imaginário das famílias é que qualquer criança ou adolescente, a qualquer momento, poderia tornar-se vítima da ação criminosa de um aluno adolescente. $\mathrm{Na}$ verdade, tanto este sentimento angustiante e a insegurança dele decorrente quanto a forte reação de indignação da sociedade são compreensíveis, já que um dos momentos de tranqüilidade para os pais sempre foi aquele em que seus 
filhos atravessavam a porta da escola, onde estariam protegidos e seguros.

Como a maioria dos jovens e crianças freqüenta a escola pública e grande parte dos atos violentos envolvia jovens do ensino médio noturno, houve forte cobrança de ações rápidas e eficientes do Governo, que, por sua vez, não se manteve omisso, agindo rapidamente.

Dois tipos de ações foram pensadas: uma de proteção física nas escolas - colocação de grades, câmeras de vídeo, policiamento, etc.; e outra de natureza mais preventiva. Neste último caso, pelo menos dois grandes programas foram gestados: Programa Jovem Cidadão: Meu Primeiro Trabalho e o Programa Parceiros do Futuro. No que diz respeito ao PJC, acreditavam os formuladores que a possibilidade de acesso ao primeiro trabalho criaria expectativas positivas entre os jovens, afastando-os da sedução da marginalidade. De certa forma o programa foi pensado como uma proteção contra o contágio da violência, embora os elevados índices de desemprego entre jovens concluintes do ensino médio (48\%) fosse referência constante.

É importante chamar a atenção para este contexto, porque deixa explícito um dos principais mecanismos pelos quais as políticas sociais acabam sendo desfocadas do público mais necessitado - trata-se do poder de pressão dos grupos mais organizados, ou, no caso, da mídia, que chega com mais facilidade aos ouvidos dos governantes e das estruturas estatais.

\section{O DIAGNÓSTICO E O DESENHO DO PROGRAMA}

Diante da pressão de famílias e professores, que ocupavam grandes espaços na mídia relatando casos de violência e exibindo elevados índices de desemprego juvenil, o governo resolveu reagir atribuindo a uma assessoria direta a responsabilidade pela formulação de proposta que equacionasse as dificuldades enfrentadas por jovens em sua entrada no mercado de trabalho. A equipe concluiu algo que, na verdade, já havia se transformado numa espécie de truísmo, tal a forma como se repetia em vários fóruns: o problema dos jovens é que eles experimentavam uma espécie de círculo vicioso - não conseguiam trabalho porque não tinham experiência, mas como adquirir experiência sem ser aceito para um trabalho? Diagnóstico simples, solução simples.

Tendo em vista que seria importante gerar estímulos para as empresas empregarem mais trabalhadores jovens, o Governo decidiu por dois tipos de subsídios: contribuir com $\mathrm{R} \$ 65,00$ (equivalente à metade do valor da bolsa do estágio); e desobrigar o empresário da carga tributária trabalhista. Pressupunha-se que tais medidas seriam um bom estímulo ao empregador, pois o pressuposto era que os empregadores estavam à procura de uma ampliação do seu quadro de empregados e somente não o faziam por falta de condições de arcar com seus custos.

Além disso, como era consenso entre a equipe de que $o$ principal problema era a falta de experiência, a proposta procurou atuar também no lado da oferta. Como o número de demandatários seria maior do que o Programa poderia atender, a idéia foi ampliar a oferta de vagas restringindo o tempo que cada jovem poderia permanecer no Programa. Encarado desta forma, quase como um processo pedagógico, o trabalho deveria ter o caráter de estágio. Finalmente, diante das dificuldades que o Brasil e São Paulo apresentam para gerar novos postos de trabalho, era sempre destacada a precaução de impedir que os mais velhos fossem despedidos para dar lugar aos jovens, ou, como costumava comentar, evitar que o filho ocupasse o lugar do pai.

Com este conjunto de elementos, todos baseados numa leitura simples da realidade e de fácil domínio no nível do senso comum, geraram-se as diretrizes básicas do Programa, que foi instituído pelo Decreto Estadual no 44.860/2000.

Assim, o PJC visava proporcionar aos estudantes de 16 a 21 anos, do ensino médio do sistema público do Estado, uma primeira chance de inserção no mercado de trabalho, por meio de estágios. Viabilizados através de parcerias com a iniciativa privada e entidades da sociedade civil sem fins lucrativos, os estágios teriam duração de seis meses, assegurando aos jovens beneficiários uma vivência profissional prática, com a cobertura de uma bolsa de $\mathrm{R} \$ 130,00$, metade paga pelo governo estadual, metade pela empresa. Em princípio, jovens em situação social mais vulnerável - por razões de pobreza, baixa escolaridade, chefia de família feminina - teriam prioridade.

A meta seria atingir, em três anos, 270 mil estagiários, assim distribuídos por semestre: $20 \mathrm{mil}, 35 \mathrm{mil}, 50 \mathrm{mil}, 50$ mil, 50 mil e 65 mil.

Quanto à sua operacionalização, o Programa teria caráter matricial, envolvendo diferentes órgãos do Governo. A coordenação ficou no gabinete do governador e a execução foi realizada por três secretarias estaduais: do Emprego e Relações do Trabalho (Sert); da Educação (SEE); e da Ciência, Tecnologia e Desenvolvimento Econômico (SCTDE). Envolvia também a Fundação de Desenvolvimento Administrativo (Fundap), responsável pelo gerenciamento dos recursos humanos (recrutamento e 
treinamento de monitores e supervisores), a Companhia de Processamento de Dados de São Paulo (Prodesp), que respondeu pela montagem e gerenciamento dos cadastros do Programa, e, finalmente, a Fundação Seade, responsável pelo monitoramento e avaliação do Programa.

Coube à Sert, coordenadora do Programa, realizar convênio com a iniciativa privada para a disponibilização de vagas de estágio, administrar o pagamento da bolsa-estágio, além de fazer o acompanhamento profissional.

A SEE e a SCTDE (que abriga as escolas técnicas) ficaram incumbidas de disponibilizar, nas próprias escolas, espaços para a inscrição dos jovens, além de colaborar na divulgação e no acompanhamento escolar.

$\mathrm{Na}$ seleção, os inscritos foram hierarquizados de tal forma que os menos favorecidos teriam mais chances (jovens com maioridade, sem experiência anterior no mercado de trabalho formal, com filhos, pertencentes a famílias com chefe com menor instrução). Ao receber as informações relativas às vagas disponibilizadas, o aluno era encaminhado, obedecendo a uma ordem de prioridade de discriminação positiva com relação àqueles que teriam menos chances em processos convencionais.

Além desta preocupação com a discriminação positiva, mais duas informações eram consideradas no processo de encaminhamento: a preferência do aluno por uma área profissional; e a localização da vaga (de preferência na mesma região de sua escola).

Para cada vaga disponível seriam convocados três alunos para entrevistas com o empregador, que faria a escolha segundo critérios próprios. O jovem aprovado na entrevista assinaria o Termo de Compromisso, que é o documento que oficializa o estágio.

Estava previsto, também, o acompanhamento profissional e escolar do jovem, bem como a formação de uma equipe de gerenciamento, avaliação e monitoramento contínuo. Instalada na Sert, a equipe era apoiada por informações de monitores com ensino superior, que acompanhariam o Programa nas escolas, e por supervisores, elo entre gerentes e monitores.

A complexidade da logística de implementação, o volume de recursos envolvidos tanto nos repasses de subsídios aos alunos e às empresas como na sustentação de uma complexa estrutura de operacionalização e ainda o fato de estar diretamente vinculado ao gabinete do governador mostram a importância que o governo dava ao Programa e a expectativa que ele havia gerado.

Como bem coloca a coordenadora da avaliação do programa no Seade: se, por um lado, o "desenho organizacio- nal revelava a prioridade do programa na agenda do governo", por outro, potencializava a geração de "conflitos entre órgãos setoriais participantes e entre estes e a coordenação do programa, como de fato se verificou". Pouco tempo após o início do seu funcionamento, havia um enorme acúmulo de problemas das mais diferentes naturezas que, associados ao falecimento do governador Mario Covas, levaram "à transferência da coordenação do programa para a Secretaria do Emprego e Relações do Trabalho" (Carvalho, 2002:7).

Ao ser transferido para a Sert, o Programa passou a receber o mesmo tratamento que os demais ali desenvolvidos. ${ }^{2}$ Neste novo espaço, o Programa perdeu força e deixou mais explícitas suas fragilidades e inconsistências.

\section{OS EQUívOCOS}

\section{O Falso Diagnóstico das Causas e das Conseqüências do Desemprego Juvenil}

A despeito da sincera intenção do governo de atuar na resolução do problema, muitos foram os equívocos cometidos desde a formulação do Programa. Destacam-se os que se seguem.

\section{As Causas}

Certamente, o maior equívoco do Programa está no diagnóstico das causas do desemprego juvenil: apostar que os altos níveis de desemprego juvenil decorrem, sobretudo, da dificuldade de romper, através de uma primeira oportunidade, o círculo vicioso imposto pela exigência de experiência anterior para o início no mundo do trabalho. Visto desta perspectiva, o problema do desemprego juvenil resume-se, basicamente, ao acesso ao primeiro trabalho.

A literatura técnica acadêmica (nacional e internacional) sobre o tema, mesmo consciente dos graves problemas que representa a desocupação juvenil, argumenta não ser esta a explicação para este complexo e aflitivo fenômeno social. O acompanhamento da implantação e do desempenho do PJC mostra uma série de evidências que dão consistência empírica a esta literatura.

A questão do crescimento da taxa de desemprego tem enorme destaque na agenda social das últimas décadas, tanto nos países desenvolvidos como naqueles em desenvolvimento. De forma bem sucinta, os índices de desemprego representam a falta de capacidade da economia de 
um país em oferecer todo o trabalho produtivo que a sua população deseja. Diferentes segmentos da sociedade apresentam dificuldades diferenciadas de acesso ao trabalho produtivo, por um conjunto diversificado de situações. Entretanto, os indicadores de desemprego juvenil sempre foram os mais elevados não só no Brasil, como em todo o mundo. O mais instigante é que esta situação persiste mesmo nos períodos de expansão econômica.

Sobretudo por tal persistência, este tema tem sido objeto de estudo da literatura internacional desde meados dos anos 70. Parte dos trabalhos tenta entender o diferencial do comportamento juvenil através de exaustivas comparações com o comportamento das outras categorias etárias, enquanto outros detêm-se nas dificuldades de enfrentar o problema, analisando detalhadamente os obstáculos com os quais se depararam os inúmeros programas de combate a este desemprego já implementados em diferentes países.

No Brasil, ao contrário, apesar do enorme desconforto que este fenômeno tem representado para a sociedade e das reais preocupações dos governos com o tema, são poucos os estudos que mergulharam numa busca de entendimento mais profundo, técnico-acadêmico desta questão.

Uma possível explicação para a pouca importância dada a estes estudos mais aprofundados, provavelmente, está no fato de aqueles que se envolveram com a questão acreditarem já conhecer muito bem o diagnóstico. Três explicações têm sido as mais recorrentes. Uma coloca a questão no contexto das grandes mudanças ocorridas na estrutura do emprego nas últimas décadas, no Brasil e em especial na RMSP: o processo de reestruturação produtiva que diminui os postos de trabalho aliado às novas demandas em relação à qualificação da mão-de-obra, alterando a preferência do empregador quanto à faixa etária do empregado. Combinando requisitos referentes à experiência profissional, escolaridade e atitude pessoal, os empregadores estariam dando preferência à população adulta. Uma segunda explicação, colocada por demógrafos, destaca a importância da pressão demográfica desta coorte etária. E, finalmente, uma terceira, inspirada no depoimento recorrente dos próprios jovens, suas famílias e dos empregadores e que a rigor orientou conceitualmente o Programa, diz respeito à crença de que o jovem não tem oportunidade no mercado de trabalho por não ter experiência ou habilidades demandadas pelo mercado, dificultando enormemente a busca do primeiro emprego.

Para debater essas questões toma-se como ponto de partida um resumo elaborado a partir de uma publicação da Organização para o Desenvolvimento e Cooperação Econômica-OECD, de 1980, intitulada $O$ desemprego dos jovens - as causas e conseqüencias, que realiza uma espécie de estado da arte dos estudos sobre o desemprego juvenil e de avaliações de políticas já implementadas para enfrentá-lo. O estudo refere-se basicamente à Europa nos anos 70 , quando esta questão já era preocupante. O surpreendente é que grande parte dos pressupostos e explicações utilizados entre nós para justificar o conceito e o desenho de políticas, para enfrentar e/ou minimizar este problema, já era questionada por ocasião desta publicação. Diante da sua surpreendente atualidade, apresentase, a seguir, um breve resumo de algumas das conclusões desta publicação.

A Literatura do Final dos Anos 70 - Resultados de um conjunto robusto de estudos que compõem a citada publicação da OECD concluem que os grandes diferenciais, sempre desfavoráveis, do desemprego juvenil decorrem da maior rotatividade dos jovens no trabalho, de uma mais alta propensão de transitar do emprego para o desemprego ou para a inatividade. Em decorrência deste fato, os estudos sobre desemprego juvenil que centralizam suas análises na medida da taxa de desemprego estática (como fazemos), sem captar a dinâmica do processo de entrada e saída do mercado de trabalho e da PEA, tendem a mascarar esta especificidade do desemprego juvenil. A dinâmica da alta transição do emprego para o desemprego ou para a inatividade é muito mais comum entre adolescentes, tendendo a se diluir à medida que avançam para idades adultas. Os estudos mostram que o desemprego diminui com o aumento da idade, de forma consistente, porém não por causa da idade $-o$ jovem tem dificuldade de ser aceito para um trabalho devido ao tempo de permanência em um trabalho, ou seja, a pouca experiência adquirida em outro emprego. Conclusões desta natureza têm se repetido em trabalhos internacionais mais recentes, inclusive no Brasil.

Apesar deste comportamento juvenil ser bastante generalizado, os estudos alertam para a existência de um grupo de jovens que apresentam uma dinâmica diferenciada passam longos espaços de tempo sem emprego, intercalados por breves períodos com empregos que consideram insatisfatórios (e a maioria efetivamente é). Pode-se encontrar jovens com estas características em todos os estratos socioeconômicos, mas eles estão amplamente concentrados em grupos que acumulam múltiplas desvantagens, como baixo nível educacional, minorias étnicas, jovens que moram em lugares distantes dos centros de trabalho, aque- 
les que convivem com ambientes de transgressão, etc. Ou seja, existe um "núcleo duro" de jovens que acumulam fragilidades sociais e que efetivamente têm dificuldades de entrar e permanecer no mundo do trabalho. Há fortes indícios de que, entre estes jovens, os problemas de empregabilidade tendem a não desaparecer com o tempo, de tal forma que quem acumula este tipo de desemprego está destinado à pobreza. Assim, enfatizam estes estudos, se quisermos efetivamente colaborar para romper o circuito da miséria, o ideal seria que os programas se concentrassem nestes jovens que acumulam desvantagens que comprometem seu futuro e também o do país.

Um grande consenso entre os pesquisadores é, naturalmente, o de que a melhor política de prevenção para o desemprego começa nos bancos escolares, de preferência com uma boa educação. Partindo desta afirmação, os autores sugerem que concentrar esforços em adolescentes que estão estudando ou recém-formados não parece ser uma boa estratégia de política social destinada a empregar jovens, já que as análises de trajetória de inserção no mercado de trabalho indicam claramente a existência de um período de adaptação até que o jovem se estabilize num emprego. Segundo os autores, este alerta vale sobretudo quando se trata de políticas que envolvem subsídios e que, portanto, custam caro aos cofres públicos. Um dos riscos mais comuns desta política é o de acabar favorecendo exatamente os jovens que só necessitariam de um tempo para conseguir se estabilizar em um trabalho, em vez daqueles que estão genuinamente com grandes dificuldades de entrar e nele permanecer.

Por este motivo, a sugestão é concentrar as políticas na faixa etária de 20 a 24 anos entre jovens que abandonaram a escola precocemente e apresentam história de longos períodos de desemprego. Neste caso, costuma ser mais eficiente a combinação de uma política que mescle ensino formal, ensino profissionalizante e políticas de subsídios, enfim, programas que melhorem a empregabilidade.

Os autores alertaram, ainda, que é vital, em qualquer política que pressuponha a contratação de jovens com o objetivo de ganhar habilidades, qualificação e socialização no mundo do trabalho (portanto, proposta típica de estágios), o envolvimento com muita convicção do empregador nesta tarefa, sobretudo quando a política inclui repasse de subsídios ao empregador. O mais interessante é o argumento desenvolvido para justificar a importância do envolvimento e convicção do empregador, concentrandose na questão da auto-estima. Como se sabe, um dos impactos mais importantes e desejáveis dos programas para jovens com baixo potencial de empregabilidade é o crescimento da autoconfiança e da auto-estima. Entretanto, argumentam com razão alguns pesquisadores, se o programa resultar em um grande número de jovens fracassados, seja pela rejeição no momento da contratação, seja pela dispensa por incompetência, indisciplina, ou simples preconceito, o programa acabará tendo o efeito oposto. Quanto mais rigoroso for o processo de seleção e de exigência no desempenho das funções, maior será o sentimento de rejeição.

Além disso, caso não haja conviç̧ão, os empregadores tendem a investir pouco no treinamento dos empregados subsidiados por saberem que o subsídio termina logo. Por este motivo, os implementadores das políticas de geração de empregos para jovens, sobretudo quando se trata de políticas que envolvem um grande número de beneficiários, precisam de bons controles para evitar tais desvios, o que exige, do ponto de vista administrativo, uma boa estrutura, freqüentemente dispendiosa.

Portanto, já no início dos anos 80 , a literatura sobre o tema adverte quanto ao conjunto de exigências, para evitar lançar programas que criam, entre os jovens e suas famílias, muita esperança hoje e frustração amanhã.

A Literatura do Final dos Anos 90 - Estudo de Flori (2003) reforça as conclusões sobre o papel decisivo da maior rotatividade dos jovens na explicação dos elevados e persistentes índices de desemprego juvenil. Este reforço vem tanto da revisão da bibliografia internacional e nacional mais recente, como das evidências colhidas pela autora.

Barros et al. (1997) investigaram a variação da incidência e a duração do desemprego nas regiões metropolitanas brasileiras, discriminando seis diferentes dimensões do desemprego. No que diz respeito ao tema idade, constatou-se que os adolescentes apresentam alta probabilidade de entrada e saída do desemprego, ou seja, grande rotatividade. Ao procurarem estabelecer uma relação entre as especificidades do desemprego juvenil e os temas da desigualdade e da pobreza, os autores concluíram que a magnitude do desemprego juvenil certamente contribui para o aumento da desigualdade de renda individual, mas terá um impacto bem menor sobre a desigualdade e a pobreza familiar, porque a renda do trabalho dos jovens colabora muito pouco para o orçamento familiar. O resultado para o conjunto da população trabalhadora, por faixas etárias, é o seguinte: o desemprego diminui conforme aumenta a idade, o que está associado à queda crescente na probabilidade de entrada na condição de desempregado ou a 
um crescimento, com a idade, na probabilidade de saída do desemprego, ou a ambos. Menezes-Filho e Picchetti (2000) analisaram os determinantes da duração do desemprego na RMSP, exatamente na área de atuação do PJC. Utilizando método diferente, no caso o estimador de Kaplan-Meier, os autores chegaram a resultados muito semelhantes.

No plano internacional, tomando como referência os trabalhos citados por Flori, embora a situação do desemprego dos jovens a partir dos anos 70 só tenha se acentuado, pouco se avançou em termos de entendimento e soluções para o problema. Fisher (2001) concluiu que a alta taxa de desemprego entre jovens nos Estados Unidos é um fenômeno persistente, que decorre da grande rotatividade de entrada e saída do mercado de trabalho, que, por sua vez, é explicado pelo fato de os jovens não serem os responsáveis pelo sustento da família, podendo dar-se ao luxo de esperar o emprego "certo".

Particularmente instigante é o resumo que a autora faz do trabalho de Blanchflower e Freeman (apud Flori 2003), que se detêm no estudo das dimensões da deterioração do mercado de trabalho dos jovens nos países da OECD, nos anos 80 e 90, mostrando que pouco se avançou em relação às inquietações e conclusões dos anos 70 .

"Neste período, a participação dos jovens na população caiu na maioria dos países, enquanto a oferta de emprego se direcionou aos setores que empregavam relativamente muitos jovens. Apesar dessas tendências e do crescente número de jovens que se dedicam apenas a estudar, a situação do jovem piorou em relação ao adulto: salários e taxas de emprego caíram, e as taxas de desemprego subiram em todos os países. Os autores estudaram os setores que mais empregam jovens, e, ao investigar se o emprego, nesses setores, estaria caindo, o que explicaria o mau desempenho do mercado de trabalho juvenil, encontraram o oposto: o emprego aumentou em relação ao emprego total. Muitos analistas esperavam que os problemas do jovem acabassem quando a geração 'baby boom' se tornasse mais velha e em seu lugar entrasse um menor número de jovens. Porém, esse trabalho mostrou que isto não ocorreu, o emprego e os ganhos dos jovens diminuíram em quase todos os países da OECD" (Flori, 2003:12).

No seu próprio trabalho, Flori (2003) procurou reunir evidências empíricas sobre a existência, nas áreas metropolitanas brasileiras, da maior rotatividade juvenil - duração do desemprego ou a taxa de entrada no desemprego e sobre os fluxos de entrada e saída da força de trabalho. Seus resultados trazem elementos para responder à ques- tão: será mesmo a dificuldade de obter o primeiro emprego que faz com que os jovens apresentem uma taxa de desemprego tão alta, ou será a alta rotatividade no mercado de trabalho juvenil? Trata-se de questão importante e atual no Brasil porque, segundo a autora, "caso o motivo dessa maior taxa estiver associado à dificuldade de se encontrar o primeiro emprego, isso pode ser considerado um problema passível de intervenção governamental. Entretanto, o principal motivo pode ser, simplesmente, a maior taxa de transição do emprego para o desemprego, ou seja, o jovem entra e sai de um emprego em um curto período de tempo" (Flori, 2003:4). Caso seja este o motivo, a questão é: vale a pena o governo gastar recursos num programa desta natureza?

Flori (2003:19) mostra que "na RMSP, pouco mais de $10 \%$ dos jovens que entram no desemprego, neste período estudado, estão à procura do primeiro emprego, enquanto mais de $80 \%$ deles já tiveram empregos anteriormente (...) logo, a procura do primeiro emprego não tem muita influência nessa alta taxa de desemprego juvenil". Destaca-se que os valores variam muito pouco entre as demais metrópoles analisadas pela autora.

Se os resultados são estes, a questão central deslocase dos determinantes das altas taxas de desemprego juvenil para aqueles da alta taxa de rotatividade juvenil. Nesta área, os trabalhos empíricos se dedicaram menos e não conhecemos resultados conclusivos. Teoricamente, o jovem pode desligar-se do trabalho por iniciativa própria ou do empregador, entretanto, de qualquer forma, trata-se de um teste de ambos os lados, pois sem história de trabalho o empregador conhece pouco do jovem, assim como o jovem, inexperiente, conhece pouco da natureza do trabalho que irá desempenhar.

Zylberstajn foi bem pedagógico e criativo, em artigo recente, para explicitar estas conclusões ainda restritas às áreas acadêmicas. Diante da polêmica instalada no país, dada a decisão do Governo Lula de gerar um programa de primeiro emprego, o jornal colocou para dois professores de economia a seguinte questão: o subsídio ao primeiro emprego é uma boa medida? A resposta do professor Zylberstajn foi não, comparando a situação de primeiro emprego com a do primeiro namoro.

"Os jovens têm dificuldade em permanecer muito tempo nos primeiros empregos. Para entender por quê, basta comparar a procura de emprego à busca do casamento. Em geral, os jovens não se casam com o primeiro namorado. Eles não têm dificuldades para encontrar um namorado, mas seus primeiros romances são curtos. 
Com o passar do tempo, os jovens ficam experientes, encontram alguém e formam, então, um par mais permanente. A proporção de 'avulsos' entre os jovens é mais alta do que entre os mais velhos não porque os jovens não namoram, mas porque os namoros são mais curtos. Há sempre muitos jovens 'procurando emprego' namorados. E é bom que seja assim, pois a rotatividade nos romances da juventude acaba produzindo melhores encontros definitivos.

Com o emprego é a mesma coisa. Os jovens 'rodam' mais porque experimentam as empresas e são experimentados por elas. Isso é bom. Com o tempo, encontram uma vaga $\mathrm{e}$ criam um vínculo mais duradouro" (Zylberstajn, 2003).

Este conjunto de considerações ajuda a entender melhor os resultados da elevada proporção de afastamentos de jovens ao longo da execução do PJC, pois, independente do período considerado, entre $30 \%$ e $35 \%$ dos jovens interromperam o estágio antes de completar os seis meses previstos. As interrupções por motivo de inadequação por parte do aluno e/ou empresa responderam por $51,3 \%$ dos casos. Pela norma, os desligamentos por inadequação, durante os primeiros 60 dias de estágio, não excluem o aluno do Programa, retornando-o ao montante dos candidatos. Também com pouca variação ao longo do Programa, os demais motivos de afastamento apresentaram as seguintes proporções: em torno de $15 \%$ ocorreram por iniciativa dos alunos e $5 \%$ por decisão da empresa. A parcela que deixou o estágio por conseguir uma outra colocação gira em torno de $5 \%$ e menos de 7\% foram efetivados. Em dezembro de 2002, quase a metade dos inscritos concluiu os estágios, com variações nos índices conforme o tamanho e o setor de atividade da empresa. Os maiores empregadores e onde também os estágios finalizam em maiores proporções são os setores prestadores de serviços e o comércio, sendo que a representação da indústria é de cerca de $10 \%$ (Fundação Seade, 2002).

Não foram realizados estudos tentando comparar a rotatividade do total do mercado juvenil com a significativa rotatividade apresentada pelo PJC e nem aqueles que pudessem verificar até que ponto a empregabilidade dos jovens que passaram pelo PJC é diferente do conjunto dos jovens, até porque é cedo para fazer acompanhamento de egressos. Entretanto, quando se leva em conta que a contratação dos jovens foi altamente subsidiada e que, além disso, o PJC contou com um alto custo de estrutura na sua operacionalização, talvez devêssemos levar muito a sério as considerações e sugestões de Hélio Zylberstajn. Para ele, a política de subsidiar o primeiro emprego é um erro, e sobretudo um enorme desperdício, porque os vínculos empregatícios ou os "casamentos" (na simbologia que ele criou) não durariam. Para ele, seria melhor ajudar o mercado a fazer a rotatividade necessária entre eles, mas com menor tempo de procura de empregos e com menores custos para as empresas.

Como realizar esta proposta será objeto do último item do texto, que realiza um balanço e faz recomendações. Por ora, vale uma reflexão colocada desde os anos 70: ao optar por focalizar o programa em adolescentes estudantes, não estaria o governo auxiliando exatamente quem precisa apenas de tempo para se ajustar, deixando de fora os mais necessitados de ajuda? Parece que sim, como será visto no decorrer do texto. Antes, porém, apresentam-se algumas reflexões sobre os equívocos do diagnóstico das conseqüências.

\section{As Conseqüências}

As políticas de geração de emprego para jovens representam hoje, no Brasil, ação de absoluta prioridade. Como visto, o diagnóstico recorrente das causas deste fenômeno atribui um peso explicativo considerável para a dificuldade que o jovem tem de romper a barreira da falta de experiência na busca de sua primeira colocação. Como argumentado anteriormente, considera-se este diagnóstico equivocado. Já no que diz respeito às conseqüências do desemprego juvenil, a questão da violência entre jovens aparece invariavelmente com destaque e, portanto, faz parte do elenco de justificativas para priorizar esta ação. A seguir argumenta-se que este raciocínio também é equivocado.

O discurso que combina desemprego juvenil e violência está na fala e na demanda de jovens e de suas famílias, sendo constante na mídia. Entretanto, a literatura latinoamericana está repleta de exemplos de programas de geração de emprego para jovens pensados e desenhados como resposta à escalada dos níveis de transgressões graves e criminosas na juventude dos setores mais carentes da sociedade, mas que na prática não mostraram qualquer impacto sobre os indicadores agregados, seja de desemprego seja de ações litigiosas. Uma ótima referência sobre os enganos desta natureza já cometidos e repetidos por gestores públicos na América Latina é o texto de Ernesto Rodríguez (2002).

Desde logo, é preciso advertir que não se está, aqui, negando as possíveis e muito prováveis conexões entre cenários da pobreza, sempre muito degradados e marcados por elevados índices de desemprego de jovens, e a vulnerabilidade juvenil ao contágio de atos violentos. O que se está 
argumentando é que da forma como costumam ser concebidas as ações, acabam por beneficiar um pequeno número de jovens, sendo muito pouco provável que entre os poucos beneficiados estejam os transgressores em potencial. Até porque o número relativo de jovens que cometeram atos ilícitos e estão em conflito com a lei é muito pequeno. Ao longo do texto, esta argumentação fica mais clara.

\section{Subestimação do Efeito Estigma}

Desde a concepção do Programa houve, na equipe, forte disposição de favorecer os jovens em situações de maior fragilidade familiar e de carências. Para isto, foi criada rígida ordem de prioridades, que deveria ser cumprida à risca. Entretanto, logo nas primeiras semanas de implementação do Programa, ficou evidente a dificuldade de cumprir esta forte convicção.

O primeiro critério a ser mudado foi o da idade. Embora o Programa preconizasse a preferência pelos mais velhos, era muito difícil encontrar jovens maiores de 17 anos que nunca tivessem trabalhado. Desta forma, foi concentrado em jovens entre 16 e 17 anos.

Pesquisa realizada com aos monitores descreve o empenho deles junto às escolas para cumprir a agenda da discriminação positiva e suas constantes frustrações por não conseguir realizá-la.

A equipe sentiu o problema como uma espécie de choque com a realidade, embora ele seja vastamente conhecido na literatura de mercado de trabalho como "efeito estigma": os empresários resistem em contratar os que moram longe do trabalho, os que têm menos qualificação, os mais pobres e os discriminados por cor, sexo, etc. Assim, a equipe foi se dando conta das armadilhas sociais que sedimentam a persistência da desigualdade e diluem os impactos dos programas de natureza compensatória nos valores agregados da desigualdade. O problema maior parece estar mesmo na distância, no morador das "periferias", já que o empregador costuma alegar o custo do transporte, o maior risco de atrasos e absenteísmo dadas as distâncias e congestionamentos comuns nas metrópoles, além do ambiente "ruim" de determinadas regiões, estereotipadas como focos de criminalidade, violência e transgressão. Além disso, os próprios jovens e suas famílias explicitam a distância como grande problema - o gasto com transporte e a dificuldade de conciliar escola e trabalho.

Segundo as regras do PJC, para cada vaga seriam encaminhados três pretendentes ao cargo, todos em situação de fragilidade familiar. Na prática, para cada vaga eram entrevistados em média de sete a nove candidatos, e o escolhido, quase sempre, não respeitava a ordem de carência, sobretudo porque a escolha acabava por privilegiar os moradores das áreas mais centrais. Ao final, foi ficando claro para a equipe o que a literatura já adverte: vão assumindo os postos aqueles que os conseguiriam de qualquer modo, sem a intervenção do Programa.

Não foram realizadas análises de acompanhamento dos egressos do PJC, apenas uma pesquisa qualitativa com exestagiários do Programa, que, de uma forma geral, avaliaram bem o PJC. Afirmaram que o estágio tem proporcionado experiência válida no que se refere a aprender a se relacionar, adquirir confiança, capacidade de tomar iniciativas e de se expressar. Respostas com este teor foram muito mais freqüentes do que, por exemplo, a aquisição de conhecimentos específicos. Dois aspectos, ambos positivos, foram recorrentes na fala dos jovens: a declaração do interesse pela continuidade dos estudos, com o ingresso no ensino superior ou a procura de cursos profissionalizantes e de línguas; e a influência do estágio na escolha de uma área profissional, relacionada positiva ou negativamente à experiência com o estágio. Em síntese, os exestagiários apontaram mais para um crescimento individual e social do que para a aquisição de conhecimento numa habilidade específica. O resultado, sem dúvida, é positivo. Entretanto, estaria respondendo à demanda por experiência exigida pelo empregador?

Seria um estudo valioso conhecer os efeitos sobre aqueles que, por qualquer um dos motivos, não conseguiram entrar no Programa ou concluir o estágio por decisão própria ou desligamento do empregador, que é um número muito grande de jovens. De fato, entre o início da implantação, maio de 2000, e junho de 2003, o PJC acumulou um total aproximado de 390 mil jovens inscritos, aos quais foram disponibilizadas 25.728 vagas de empresas que aderiram ao Programa. Os postos oferecidos foram preenchidos com a contratação de aproximadamente 38 mil estagiários, pois algumas vagas foram ocupadas mais de uma vez antes do encerramento do estágio, em função da inadequação à atividade. A julgar por estes números, a quantidade de jovens que se frustraram com o Programa foi muito maior que a daqueles que se beneficiaram.

Mesmo sem ter sido realizada análise detalhada sobre o perfil dos jovens que freqüentaram os melhores empregos e o daqueles que, por qualquer motivo, tenham ficado de fora, permanece a forte impressão de que os adolescentes que participaram do Programa nas melhores vagas teriam as melhores chances com ou sem o Programa. 
Diante do exposto, repetimos a pergunta: será que aqueles que concluíram o estágio adquiriram "experiência", conforme a expectativa do Programa e dos empregadores? É deste tema que tratamos a seguir.

Tomando como referência o depoimento nas pesquisas qualitativas, a resposta mais provável a esta última pergunta é não. Da ótica do empregador, experiência significa, sobretudo, tempo de registro em carteira de trabalho, entretanto, os jovens que participaram do programa não têm sua carteira de trabalho assinada e reclamam muito desta situação. ${ }^{3}$ Na prática, portanto, as atividades desenvolvidas pelos estagiários que não foram admitidos (só $6 \%$ foram admitidos) e/ou não trabalharam em grandes organizações (a porcentagem é pequena) não diferem muito das ocupações típicas de entrada no mercado de trabalho, de caráter transitório (na visão dos jovens e na prática do mercado), como descreve Elenice M. Leite (2002), em relatório de pesquisa qualitativa realizada em áreas periféricas da RMSP. De fato, "grande parte dos jovens transitam quase que exclusivamente em relações de trabalho informais (sem proteção social), mas exercidas em contextos protegidos de negócios familiares e/ou com vizinhos e conhecidos: ajudantes de pais em restaurantes e barracas (feira livre, churrasco); cobrador (de dívidas); entregador de confecções (na empresa da mãe); digitação de trabalhos escolares em casa; babá de vizinhos e parentes; artesanato 'hippie'. Uma das vantagens deste tipo de trabalho é a sua compatibilidade com a escola, o que é possível, em grande parte, pelo contexto amigável (familiar/vizinhança) em que trabalham, já que a sinalização do mercado de trabalho sobre a importância do estudo está presente inclusive entre as famílias mais pobres. A interrupção da vida escolar decorre mais de processos de rebeldia do que da pressão para trabalhar".

Da mesma maneira, "a prática de procurar emprego se dá de forma assimétrica, nos intervalos do tempo de escola/trabalho - ou uma ou duas vezes por semana. Em finais de ano, a busca se intensifica, aproveitando a conjuntura de férias escolares e maior oferta de trabalho temporário no comércio e serviços, justamente do tipo a que podem aspirar, como ajudante de vendas, caixa, entregas, pacotes, embalagens e similares" (Leite, 2002:25). ${ }^{4}$

\section{Apostar Demasiadamente na Responsabilidade Social do Empresariado}

A mídia tem repercutido, de forma recorrente, a idéia de que a classe empresarial no Brasil despertou para a impor- tância e o valor estratégico de atuar na área social. A julgar pelas matérias e reportagens sobre o tema, efetivamente um conjunto grande de ações está sendo elaborado e pensado de forma criativa na área social com a ajuda da classe empresarial, o que faz acreditar que efetivamente o Brasil melhorou e que se pode esperar por melhoras ainda mais significativas.

Entretanto, se nos pautarmos pela resposta que o setor privado deu ao chamado feito pelo PJC, a conclusão é a de que a sociedade, em geral, e o setor privado, em especial, ainda não despertaram para um espaço de ação voluntária e solidária de alto valor estratégico para o Brasil de hoje e do futuro - a referência aqui é ao empenho em se organizar no sentido de colaborar para uma transição mais tranqüila do jovem no mercado de trabalho.

Nos levantamentos realizados, ficou claro que o estágio só será eficiente para o jovem e para a sociedade se o empregador incorporar o conceito de que estágio não é trabalho, mas sim uma ação que complementa a formação do jovem e que é exercida de forma voluntária e solidária por diferentes atores da organização que acolhe o estagiário. Na prática, significa que a empresa deve desenvolver um projeto com esta finalidade, que segure o jovem pela mão e o conduza no caminho da socialização no mundo do trabalho, que passa pelo conhecimento dos direitos e deveres do trabalhador, pela consciência da importância do trabalho em equipe e que chegue até o conhecimento das diferentes atividades da empresa, desde a manutenção de equipamentos até as atividades mais complexas.

Se o trabalho é voluntário, deve prescindir também de elevados subsídios, que sempre tornam o programa caro e, portanto, de baixa escala e impacto nos dados agregados.

Zylberstajn (2003) faz uma sugestão que, embora não se refira à situação de estagiário e sim de emprego, é interessante e merece ser levada em consideração: "uma possível solução é um consórcio de empregadores de jovens, uma pessoa jurídica formada voluntariamente por um grupo de empresas. Uma empresa contrataria um jovem formalmente. Se não desse certo, ele seria liberado para procurar outra empresa do mesmo consórcio. Demoraria menos para encontrar uma nova vaga, pois o jovem se candidataria automaticamente a todas as vagas oferecidas pelo consórcio. O vínculo de emprego seria com o consórcio, não com as empresas. A troca de emprego dentro do mesmo consórcio não seria um desligamento.

Enquanto o jovem estivesse 'rodando' entre as empresas do consórcio, nenhuma delas teria que pagar o aviso 
prévio nem a multa do Fundo de Garantia por Tempo de Serviço - FGTS. Depois de um certo tempo, se o jovem não tivesse encontrado o emprego segundo as suas expectativas, seria finalmente desligado, com o pagamento de todos os direitos, rateados entre as empresas que tivessem utilizado seu trabalho. Se, por outro lado, o jovem se fixasse em alguma das empresas, esta o efetivaria e ele sairia do consórcio".

A proposta contém uma série de vantagens: "reduziria o custo de contratar jovens porque o pagamento das verbas rescisórias ocorreria apenas uma vez e seria rateado. Para os jovens, os custos e o tempo de procura de emprego a cada desligamento seriam grandemente reduzidos. Mas a maior vantagem é que o governo não gastaria nada. Seria um programa de grande alcance social, sem custos para o contribuinte, pois utilizaria recursos existentes. As empresas se organizariam voluntariamente em grupos, cobrindo regiões ou bairros das grandes cidades. Os jovens seriam cadastrados nas agências públicas existentes. Os jovens à procura de emprego também se cadastrariam nessas agências, formando pools de trabalhadores disponíveis na região. As empresas estariam ajudando os jovens a se tornarem mais experientes no mercado de trabalho, mas também seriam beneficiadas, seja por diminuir o custo de contratar alguém com o perfil desejado, seja por contribuir para qualificação da mão-de-obra em geral" (Zylberstajn, 2003).

Esta parece uma boa forma de as empresas irem consolidando a sua assumida decisão de responsabilidade social com a juventude carente.

\section{Superestimação das Metas}

Certamente, um dos grandes equívocos do PJC, que provocou uma espécie de efeito dominó de desdobramentos equivocados, foi, além do superdimensionamento dos recursos, o estabelecimento de uma meta irrealista. Entre maio de 2000 e dezembro de 2002, inscreveram-se 375 mil estudantes e foram captadas 22 mil vagas no mesmo período, quantidade muito distante do objetivo, 270 mil vagas.

Para se entender melhor o tamanho do irrealismo, basta observar os números absolutos de ocupados na RMSP e a variação do saldo líquido (postos de trabalho criados menos postos eliminados) anual de postos de trabalho, a partir de 1996.

O dado que sobressai de imediato é que somente em 2000, quando a economia da RMSP atingiu seu maior ritmo de crescimento - algo em torno de 4,5\% -, o saldo líquido anual de postos de trabalho (280 mil) atingiu valor próximo à meta do programa $(270 \mathrm{mil})$. Note-se que $280 \mathrm{mil}$ refere-se ao saldo líquido do total de postos de trabalho naquele ano, considerando toda a PEA e não somente a faixa de 16-21 anos, foco do PJC.

Os resultados referentes aos anos anteriores a 2000, que a rigor deveriam estar subsidiando a definição de metas, mostram que o saldo líquido de postos criados a cada ano, para toda a PEA da RMSP, não chegava a $50 \mathrm{mil}$, sendo que em 1998, ano anterior à concepção do Programa, foram eliminados quase 100 mil postos, ou seja, um saldo líquido negativo.

Observando os números da faixa jovem, de 15 a 24 anos, no período anterior a 2000, verifica-se que os saldos líquidos eram negativos, o que, de fato, justifica a preocupação com o emprego juvenil, mas jamais a meta definida, que parece impossível de ser cumprida. Finalmente, quando se detém no foco do Programa - jovens entre 16 e 21 anos que freqüentam o ensino médio -, nota-se que o número absoluto de ocupados no período girava em torno de 170 mil, sendo que os saldos anuais eram cerca de 15 mil. $A$ rigor, é este valor que deveria estar referenciando a meta. Ou seja, o que definiu a meta foi uma estimativa da demanda por vagas e não o que seria razoável: uma estimativa do potencial de geração de vagas.

Entretanto, por que, e como, uma meta tão superestimada seria nociva para o Programa? Por vários motivos.

O primeiro e mais grave refere-se ao fato de o PJC ter sido dimensionado, no desenho organizacional e nos custos, tendo como referência esta meta. Isto gerou uma enorme e complexa estrutura organizacional, com grande número de pessoas e elevado custo operacional.

A segunda razão é que, diante da persistência da enorme distância entre o que se conseguia efetivar (estágios para jovens) e o que era a sua expectativa, o PJC passou a ser visto, tanto pelo Governo como pela equipe técnica, como algo marcado pelo fracasso e pela incompetência pessoal e institucional.

Com efeito, logo no início do Programa, foi feito um enorme esforço de cadastramento de jovens junto às escolas, resultando na inscrição imediata de 230 mil jovens, sendo que o número de vagas, no mesmo período, foi de 2.000, o que se mostrou extremamente decepcionante para o Governo e os inscritos. De certa forma, a equipe que concebeu o programa não conseguia entender o porquê do pouco interesse das empresas, já que seus pressupostos eram de que a oferta de trabalho subsidiado geraria um interesse tão grande que o problema estaria em limitar o número de estagiários solicitados por empresas. 
TABELA 1

Estimativa dos Ocupados, segundo Sexo e Idade e Freqüência ao Ensino Médio Região Metropolitana de São Paulo - 1995-2002

\begin{tabular}{|c|c|c|c|c|c|c|c|c|c|c|c|c|c|c|c|}
\hline \multirow[b]{2}{*}{$\begin{array}{l}\text { Sexo e } \\
\text { Idade }\end{array}$} & \multicolumn{8}{|c|}{ Estimativa Ocupacional } & \multicolumn{7}{|c|}{ Estimativa do Saldo Ocupacional } \\
\hline & 1995 & 1996 & 1997 & 1998 & 1999 & 2000 & 2001 & 2002 & $\begin{array}{l}1996 / \\
1995\end{array}$ & $\begin{array}{l}1997 / \\
1996 \\
\end{array}$ & $\begin{array}{l}1998 / \\
1997 \\
\end{array}$ & $\begin{array}{l}1999 / \\
1998 \\
\end{array}$ & $\begin{array}{l}2000 / \\
1999 \\
\end{array}$ & $\begin{array}{l}2001 / \\
2000\end{array}$ & $\begin{array}{l}20021 \\
2001\end{array}$ \\
\hline TOTAL & 7.135 & 7.182 & 7.217 & 7.125 & 7.170 & 7.450 & 7.596 & 7.625 & 47 & 35 & -92 & 45 & 280 & 146 & 29 \\
\hline De 10 a 14 Anos & 104 & 98 & 90 & 65 & 55 & 53 & 58 & 53 & -6 & -8 & -25 & -10 & -2 & 5 & -5 \\
\hline De 15 a 24 Anos & 1.765 & 1.733 & 1.728 & 1.688 & 1.649 & 1.757 & 1.774 & 1.709 & -32 & -5 & -40 & -39 & 108 & 17 & -65 \\
\hline $\begin{array}{l}\text { De } 25 \text { a } 39 \text { Anos } \\
\text { De } 40 \text { Anos ou }\end{array}$ & 3.031 & 3.031 & 3.050 & 3.023 & 3.019 & 3.095 & 3.158 & 3.196 & 0 & 19 & -27 & -4 & 76 & 63 & 38 \\
\hline Mais & 2.234 & 2.320 & 2.349 & 2.349 & 2.447 & 2.544 & 2.607 & 2.667 & 86 & 29 & 0 & 98 & 97 & 63 & 60 \\
\hline Homens & 4.223 & 4.205 & 4.213 & 4.165 & 4.112 & 4.292 & 4.312 & 4.326 & -18 & 8 & -48 & -53 & 180 & 20 & 14 \\
\hline De 10 a 14 Anos & 67 & 62 & 55 & 44 & 34 & 32 & 35 & 32 & -5 & -7 & -11 & -10 & -2 & 3 & -3 \\
\hline De 15 a 24 Anos & 1.008 & 986 & 995 & 971 & 931 & 983 & 995 & 969 & -22 & 9 & -24 & -40 & 52 & 12 & -26 \\
\hline $\begin{array}{l}\text { De } 25 \text { a } 39 \text { Anos } \\
\text { De } 40 \text { Anos ou }\end{array}$ & 1.747 & 1.741 & 1.742 & 1.722 & 1.711 & 1.782 & 1.771 & 1.807 & -6 & 1 & -20 & -11 & 71 & -11 & 36 \\
\hline Mais & 1.402 & 1.416 & 1.421 & 1.429 & 1.436 & 1.494 & 1.510 & 1.518 & 14 & 5 & 8 & 7 & 58 & 16 & 8 \\
\hline Mulheres & 2.912 & 2.977 & 3.004 & 2.960 & 3.058 & 3.158 & 3.284 & 3.299 & 65 & 27 & -44 & 98 & 100 & 126 & 15 \\
\hline De 10 a 14 Anos & 37 & 37 & 35 & 21 & 20 & 22 & 22 & 21 & 0 & -2 & -14 & -1 & 2 & 0 & -1 \\
\hline De 15 a 24 Anos & 757 & 747 & 732 & 717 & 718 & 774 & 779 & 740 & -10 & -15 & -15 & 1 & 56 & 5 & -39 \\
\hline $\begin{array}{l}\text { De } 25 \text { a } 39 \text { Anos } \\
\text { De } 40 \text { Anos ou }\end{array}$ & 1.285 & 1.290 & 1.309 & 1.301 & 1.309 & 1.313 & 1.386 & 1.389 & 5 & 19 & -8 & 8 & 4 & 73 & 3 \\
\hline Mais & 832 & 903 & 928 & 920 & 1.011 & 1.050 & 1.097 & 1.149 & 71 & 25 & -8 & 91 & 39 & 47 & 52 \\
\hline $\begin{array}{l}\text { De } 15 \text { a } 24 \text { Anos } \\
\text { que Freqüenta de } \\
\text { 2a à 4a Série do }\end{array}$ & & & & & & & & & & & & & & & \\
\hline Ensino Médio & 197 & 194 & 197 & 204 & 213 & 210 & 216 & 180 & -3 & 3 & 7 & 9 & -3 & 6 & -36 \\
\hline $\begin{array}{l}\text { De } 15 \text { a } 19 \text { Anos } \\
\text { que Freqüenta de } \\
\text { 2ª̀ à } 4^{\text {a Série do }}\end{array}$ & & & & & & & & & & & & & & & \\
\hline Ensino Médio & 138 & 140 & 149 & 152 & 160 & 166 & 171 & 143 & 2 & 9 & 3 & 8 & 6 & 5 & -28 \\
\hline $\begin{array}{l}\text { De } 20 \text { de } 24 \text { Anos } \\
\text { que Freqüenta de } \\
2^{\text {a }} \text { à } 4^{\text {a }} \text { Série do }\end{array}$ & & & & & & & & & & & & & & & \\
\hline Ensino Médio & 59 & 54 & 48 & 53 & 53 & 44 & 45 & 37 & -5 & -6 & 5 & 0 & -9 & 1 & -8 \\
\hline $\begin{array}{l}\text { De } 16 \text { a } 21 \text { Anos } \\
\text { que Freqüenta de } \\
\text { 2a à 4a Série do }\end{array}$ & & & & & & & & & & & & & & & \\
\hline Ensino Médio & 168 & 170 & 170 & 176 & 187 & 187 & 193 & 165 & 2 & 0 & 6 & 11 & 0 & 6 & -28 \\
\hline
\end{tabular}

Fonte: SEP. Convênio Seade-Dieese. Pesquisa de Emprego e Desemprego - PED.

De fato, o decreto governamental que instituiu o Programa estabeleceu algumas condições para a participação das empresas do setor privado, salientando que as mesmas não poderiam substituir mão-de-obra por estágio e que o número de estagiários deveria ser proporcional ao quadro de pessoal.

É interessante ressaltar que, tendo incorporado estes pressupostos, as equipes dirigentes ficavam perplexas diante das dificuldades em captar novas vagas e, pressio- nadas, se propunham, como tarefa principal, a aumentar o número de vagas utilizando novas estratégias (as quais sistematicamente mostravam-se ineficientes).

Este empenho constantemente renovado causava surpresa, porque os dados mostravam regularidade e constância no número de vagas, evidenciando o potencial efetivo do Programa, além de indicar um claro comportamento pró-cíclico, ou seja, nos momentos de melhor desempenho da economia a captação de vagas crescia, enquanto o con- 
trário ocorria nos períodos de contração, como mostram os dados apresentados a seguir.

Entre maio de 2000 e dezembro de 2002, 5.333 empresas aderiram ao PJC. O primeiro ano registrou a participação do maior número de empresas (56\%), diminuindo nos dois seguintes. A média mensal foi de 237 empresas no primeiro ano, 137 entre maio de 2001 e janeiro de 2002 e 117 de fevereiro a dezembro de 2002. A redução do número de empresas não é necessariamente um indicador de menor oferta de vagas, já que cada uma das empresas pode oferecer mais de uma vaga. Neste caso, entretanto, ocorreu efetivamente uma queda na oferta: foi captada uma média mensal de 810,624 e 628 postos, respectivamente, para os três anos considerados. Ao se tomar como indicador a relação média candidato/vaga, encontra-se, para o período analisado, os seguintes valores: 16,9 ; 11,7 e 20,9 inscritos por vaga, comportamento totalmente pró-cíclico.

Uma estimativa realizada através dos dados da PED Pesquisa de Emprego e Desemprego da Região Metropolitana de São Paulo mostra que, entre 2000 e 2002, os estagiários do ensino médio representavam cerca de $3 \%$ a $5 \%$ do total de ocupados nesta faixa etária, mas é importante lembrar que nem todos estavam no Programa Jovem Cidadão: Meu Primeiro Trabalho.

Além da dificuldade de captar vagas, as equipes se defrontaram com outro problema ainda mais angustiante: mesmo com um número tão pequeno de postos de trabalho diante das expectativas, o Programa perdia vagas. Isto ocorria porque o PJC não conseguia preencher, com a rapidez exigida pelo empregador, os requisitos mínimos de contratação, o que freqüentemente levava à perda da vaga. Em parte, isto deveu-se à complexidade do sistema montado para o encaminhamento do candidato, o qual, no esforço de tentar enviar o jovem "ideal" segundo os critérios definidos (processo extremamente demorado e complexo), acabava por perder a vaga. Além disso, o PJC se deparava com os mesmos (e conhecidos) problemas enfrentados pelos sistemas de intermediação de mão-de-obra, que, embora tendo um número imenso de pretendentes, não conseguem preencher as vagas disponíveis.

Finalmente, um outro fator de peso, também inesperado, contribuiu para diminuir o número de vagas disponibilizadas pelos empresários - a indefinição: estágio ou primeiro trabalho, tema que tratamos a seguir.

\section{A Indefinição: Estágio ou Primeiro Trabalho?}

Um dos maiores problemas que o PJC enfrentou foi a reação dos fiscais do Ministério Público do Trabalho, que, em inúmeras situações, consideraram a natureza das atividades desenvolvidas pelos jovens do PJC, nas unidades produtivas, em desacordo com a lei. Novamente, os problemas ocorreram porque os organizadores do Programa não conheciam, ou acreditavam que não era importante, a complexa discussão sobre o sentido e a natureza do estágio para o ensino médio, que recentemente, na nova Lei de Diretrizes de Base, se separou do ensino médio de caráter técnico. Nesta divisão, o ensino médio acabou perdendo o caráter profissionalizante, passando a se definir, tanto do ponto de vista curricular como conceitual, como uma preparação mais geral para a vida civil e para o desenvolvimento de competências básicas para um bom desempenho na estrutura produtiva em constante e rápida mutação.

O Ministério Público do Trabalho vinha se insurgindo contra a existência do estagiário do ensino médio nesta nova concepção, por dois motivos: a alegação de que a nova legislação retirou deste ensino qualquer grau de compromisso com a formação para o trabalho e concentrou seu objetivo pedagógico na formação geral dos alunos; e o fato de que os empresários têm se valido desses estágios como mão-de-obra de menor custo.

Com relação ao primeiro aspecto, na verdade, parte importante da tensão decorria do fato de o Conselho Nacional de Educação não ter regulamentado as regras e normas do estágio do aluno do novo ensino médio. Na edição da Lei de Diretrizes de Base (Lei n ${ }^{\circ}$ 9.394/96), ao ser instituído o novo perfil do ensino médio, com seu respectivo estágio, o Artigo 82 determinou que competia aos sistemas de ensino estabelecerem as normas para a realização dos estágios dos alunos regularmente matriculados no ensino médio ou superior em sua jurisdição. Além disso, o Artigo 88 estabeleceu que a legislação educacional e de ensino deveria ser adaptada às disposições contidas nesta Lei de Diretrizes de Base.

Ocorre que, no momento da implementação do PJC, não havia ainda sido feita a regulamentação dos estágios por parte dos sistemas de ensino. Argumentava-se, então, que, na falta de uma nova regulamentação, prevalecia aquela já existente.

Entretanto, com relação ao ensino médio, o Ministério Público do Trabalho tinha uma leitura particular, considerando que poderia ser aceita a antiga regulamentação somente para os estágios do ensino superior e da educação profissional, pois estes se coadunavam com a regulamentação existente, já que tinham prioritariamente a função profissionalizante dada pela Lei ${ }^{0} 5.692 / 71$ e sis- 
tematizada posteriormente pela Lei do Estágio ( $\mathrm{n}^{\circ}$ 6.494/ 77). Nesta lei, um dos requisitos básicos para a realização destes estágios era a obrigatória correlação entre a formação escolar específica e a atividade prática dos estágios.

Diante da nova orientação filosófica do ensino médio, o Ministério Público do Trabalho entendia que, mais do que nunca, o estágio do aluno de ensino médio deveria ter caráter sobretudo pedagógico, preparando o estudante para o trabalho e para a vida, dando-lhe condições de exercício pleno da cidadania. Sendo assim, coerente com sua proposta, caberia ao estágio do ensino médio proporcionar o conhecimento prático do ambiente do trabalho, das relações de trabalho, da estrutura de uma empresa e sua importância e papel na economia local e nacional, de modo a serem trabalhados os conceitos teóricos obtidos no âmbito da linguagem, da matemática, da história, da física e, ainda, os conceitos adquiridos sobre trabalho, sua valorização e ética, sem perder de vista, naturalmente, a realidade do mercado de trabalho e o fato incontestável de sua mutação constante. ${ }^{5}$

Enfim, ao contrário dos estágios nos ensinos superior e profissionalizante, que se voltam a uma profissão, cujos conhecimentos estão sendo adquiridos, exigindo a contrapartida prática para a inserção do profissional numa atividade específica do mercado de trabalho, o estágio no ensino médio deveria se configurar sobretudo como uma preparação básica para o mundo do trabalho, o que não deve ser confundido com "programas de primeiro trabalho".

Ocorre que, na sua concepção, o PJC fundiu, da perspectiva dos órgãos de fiscalização, de forma indevida, o conceito de estágio com o de primeiro trabalho, potencializando, portanto, um conflito constante tanto com o Ministério Público do Trabalho quanto com os Conselhos de Educação, uma vez que é sutil, em cada situação concreta, traçar claramente a fronteira entre o estágio e a relação de emprego.

Pode-se dizer que a ação fiscalizadora do Ministério Público, de certa forma, inibiu a ação das empresas, o que ajuda a explicar a dificuldade de ampliar o número de vagas para estágios. De forma geral, as leis e campanhas contra o trabalho de adolescentes têm levado as empresas a evitar situações que possam causar danos à sua imagem e outros prejuízos, o que na prática eleva o desemprego deste grupo etário.

No que diz respeito aos impactos nocivos que um programa de estágio poderia trazer sobre a dispensa de tra- balhadores no setor formal da economia, aproveitando a isenção dos encargos trabalhistas do programa de estágios, não há dados precisos. Porém, existem vários sinais de que há fortes exageros nesta preocupação. Os estagiários constituem menos de $1 \%$ do total da PEA, sendo que apenas $24 \%$ freqüentam o ensino médio. Destes, quase $90 \%$ estão inseridos no setor público. Portanto, pode-se concluir que, ao longo da implementação do PJC, o problema encontra-se mais na resistência das empresas em aceitar estagiários do que na tendência de se aproveitar dos subsídios para substituir trabalhadores, até porque os empregadores sabem que o treinamento tem um custo e o subsídio é por curta duração. Isto não significa que não existam empresas que buscam no estágio uma forma de contratar livrando-se dos encargos sociais, sem qualquer preocupação com o aspecto educativo da atividade.

A pesquisa qualitativa realizada com um grupo de empresas, em 2001, concluiu que: "elas se movem por razões egoístas - ditadas pelos interesses de qualquer empresa privada de maximização da relação custo/benefício - e por razões altruístas - dadas pelo interesse de participação em um programa com fins sociais. Contudo, o equilíbrio entre estas razões é variável entre empresas, pois, se de um lado há empresas que pretendem deliberadamente a efetivação do estagiário, por outro identificaram-se empresas que se valem do programa como alternativa ao recrutamento de mão-de-obra" temporária ou não (Fundação Seade/Sert apud Carvalho, 2002:18).

"Há, portanto, por parte das empresas, extrema heterogeneidade, pois os motivos que as levaram a aderir ao programa são individualizados, seja de oportunidade de dispor de mão-de-obra a baixos custos (...) seja movidas pelos mesmos objetivos sociais pretendidos pelo programa. De qualquer forma, o compromisso social, como mecanismo de articulação coletiva", importante para dar escala a um programa desta natureza, está muito longe de se consolidar (Carvalho, 2002:18).

\section{CONCLUSÕES: RESULTADOS, LIÇÕES E SUGESTÕES}

Do ponto de vista dos resultados puramente quantitativos, os saldos do PJC não são nada animadores. Desde sua implantação, até junho de 2003, o Programa acumulou um total aproximado de 390 mil inscrições, para as quais foram disponibilizadas apenas 25.728 vagas referentes a 6.231 empresas de várias dimensões, predominando as 
empresas de pequeno (até 15 funcionários) e grande (mais de 100 funcionários) portes, bem como aquelas dos setores de prestação de serviços e comércio. As vagas foram preenchidas com a contratação de aproximadamente $38 \mathrm{mil}$ estagiários. Do total de vagas oferecidas, em 79,4\% os jovens concluíram o estágio e em $6,2 \%$ foram efetivados. Dos afastamentos, $13,6 \%$ se desligaram por iniciativa do próprio jovem e $4,4 \%$ por parte da empresa. Portanto, o PJC ficou muito distante de sua meta e comparando o número de inscritos com os de beneficiários gerou mais frustração do que satisfação.

Não foi feita nenhuma avaliação sistemática de acompanhamento de egressos, apenas uma avaliação qualitativa, realizada com um grupo pequeno de ex-estagiários do Programa. Os resultados também foram pouco animadores. De forma recorrente, os estudantes consideraram mais o crescimento individual e social do que a aquisição de conhecimentos específicos para o desempenho de uma determinada atividade. Nada contra o crescimento da sociabilidade, apontada como desdobramento positivo pelos ex-estagiários, o que é realmente importante para o desenvolvimento da auto-estima do jovem adolescente. Entretanto, há fortes sinais de que os jovens que concluíram os melhores estágios são também aqueles que ocupam situações socioeconômicas mais favoráveis, o contrário, portanto, do que o Programa se propunha. Além disso, adquirir experiência no mercado de trabalho, agora está claro, significa para o empregador, sobretudo, o desempenho continuado de uma tarefa, de preferência realizada com a carteira assinada. Em outros termos, o Programa deixou de cumprir duas de suas mais importantes missões: chegar ao jovem mais carente e equipá-lo com a "experiência" que o setor privado demanda. Na verdade, nossas conclusões em nada diferem do ótimo resumo realizado por Jacinto (2003), quando destaca:

- "Embora não haja consenso sobre as medidas para promover o emprego de jovens e as avaliações sejam ainda muito deficientes, elas em geral coincidem no fato de que os resultados não são satisfatórios, nem para os jovens em geral, nem para os mais desfavorecidos.

- O apelo a contrato de pouca duração tem pouco efeito sobre a geração posterior de empregos estáveis.

- A maior flexibilidade dos salários pouco contribui para combater o desemprego juvenil, ou, em outros termos, os jovens não estão privados de trabalho por razões de custo.

- Os contratos de aprendizagem (estágios) não comportam-se como instâncias de formação e tampouco são con- siderados como garantia de experiência no trabalho pelos empregadores.

- Só há sinal de eficiência nos programas muito focalizados, caros, de baixa escala e difíceis de serem multiplicados".

Ou seja, o PJC, que envolveu um volume razoável de recursos públicos, não teve nenhum impacto seja sobre os índices de desemprego juvenil, seja sobre a violência, fenômenos constantemente associados e ainda uma das principais justificativas para a implementação de programas de emprego juvenil.

Entretanto, os recados mais importantes a serem deixados nesta conclusão não são os resultados apontados, os quais, de certa forma, oferecem indicações sobre o impacto do Programa. Os efeitos mais significativos desses recados dizem respeito ao tipo de avaliação aqui realizada, que difere das formas mais convencionais que priorizam os resultados dos impactos. Nesta nova conduta de avaliação, cuja ótica se aproxima mais das Ciências Sociais, priorizou-se a análise dos fatos e processos que definiram o desenho e o desenvolvimento do Programa, o que possibilitou um melhor diagnóstico do conjunto de equívocos que acabaram por tornar os resultados do programa bastante desalentadores.

Estas considerações, ou recados, estão divididas em três destaques.

O primeiro é chamar a atenção para o fato de que qualquer política social que se faça hoje, no Brasil, deve ter presente que o nosso problema não tem sido tanto a falta de recursos aplicados na área social, mas sim os gastos sociais maldirecionados, que tendem a se concentrar entre os $30 \%$ e $40 \%$ menos pobres da população. A história do sistema de proteção social no Brasil é marcada pela reprodução de privilégios por meio do corporativismo e de respostas à pressão de grupos organizados com mais acesso a estruturas sociais. Mais recentemente, a pressão e o poder da mídia também têm pautado ações de política social. A literatura já acumula um número razoável de exemplos que mostram que, de uma forma geral, políticas pensadas e desenhadas em resposta a diferentes situações contingenciais são malfocalizadas e desenhadas, e seus impactos sobre a desigualdade social tornam-se nulos ou até acentuadores desta tendência. Foi o que aconteceu com o PJC, que, em última instância, foi uma resposta ao tema da violência nas escolas que ganhara espaço espetacular na mídia. Os resultados do Programa em nada contribuíram para enfrentar a questão da desigualdade social, da violência e do desemprego juvenil. Trata-se de mais um exemplo de gasto público mal-aplicado e, para evitar desvios desta 
natureza, o desenho e o foco dos programas devem ter sempre a ampla participação de especialistas, uma área que genericamente poderia ser chamada de "tecnologia social".

O segundo destaque diz respeito à importância de vencer as resistências de incorporar, nas análises sobre políticas sociais, reflexões já realizadas pela vertente do chamado mainstream da economia, mesmo quando se pretende valorizar a perspectiva das Ciências Sociais. No caso deste artigo, o apoio nestes tipos de abordagem metodológica foi fundamental para entender que o problema do desemprego juvenil está longe de se confundir com a questão do primeiro emprego. Conforme demonstrado neste artigo, o desemprego juvenil agora e ao longo das décadas recentes, tanto nos períodos de crise quanto nos de crescimento, ocorre mais pela especificidade do comportamento dos jovens - rotatividade entre emprego e desemprego, e entre atividade e inatividade - do que pela dificuldade de obter o primeiro emprego. Além disso, é importante destacar que "falta de experiência" não significa uma simples passagem por uma situação de trabalho remunerado, mas sim o amadurecimento no desempenho de uma tarefa. $\mathrm{Na}$ verdade, todo o problema do desemprego juvenil está em abreviar esta rotatividade, na qual as políticas para jovens com níveis de escolaridade acima do ensino médio deveriam atuar. No texto, destacou-se a proposta de Hélio Zylberstajn, que sugere a formação de consórcios entre empregadores do setor privado.

A falta total de diálogo entre diferentes formas de olhar ou tratar o problema mostra a importância tanto de aumentar a ênfase em algumas disciplinas básicas - matemática, estatística, estatística avançada, computação avançada, etc. -, tornando-as parte da formação do cientista social brasileiro para que se possa produzir uma ciência social de qualidade, quanto de intensificar a produção de estudos nas áreas de mercado de trabalho juvenil, sobretudo em análises longitudinais.

Por fim, o último destaque é estimular a cultura de buscar exemplos de políticas sociais já realizadas em outros espaços e localidades, ou seja, estimular o campo das políticas sociais comparadas. O presente estudo foi muito enfático ao mostrar como a implementação de uma determinada política pública pode se beneficiar do conhecimento acumulado sobre o tema, deixando claro o acerto de Faria (2002:71) ao considerar que "a ciência social latino-americana deveria abandonar seu caráter caipira, por assim dizer, de pouca curiosidade pela pesquisa social comparada, e aumentar sua expertise e seu compromisso com os estudos comparativos".

\section{NOTAS}

1. Consideram-se famílias pobres aquelas com renda per capita familiar inferior a R\$ 90 por mês, a preços de 1999 .

2. Os principais programas em execução na Sert, naquele momento, eram "as Frentes de Trabalho, o Banco do Povo, o Programa Estadual de Qualificação e o programa de mesmo nome - Jovem Cidadão - executado por aquela secretaria em articulação com o Serviço Civil Voluntário, programa de iniciativa federal destinado ao atendimento dos jovens de 18 anos, dispensados do serviço militar e em situação de risco" (Carvalho, 2002:8).

3. A carteira de trabalho só é assinada pelo empregador quando existe a efetiva contratação para o desempenho de uma tarefa. Estágio, por definição, não é a execução continuada de uma tarefa.

4. Projeto desenvolvido em conjunto com a Universidade de São Paulo - USP, Centro de Estudos da Metrópole - CEM, vinculado ao Centro Brasileiro de Análise e Planejamento - Cebrap, em convênio com a Fundação Seade. Apoio do CNPq/ Hewlett/ Fundação de Amparo à Pesquisa do Estado de São Paulo - Fapesp.

5. Cf. Relatório do Ministério Público do Trabalho. Ministério Público do Trabalho, Procuradoria Regional do Trabalho, $2^{\mathrm{a}} \mathrm{Re}$ gião, Coordenadoria de Interesses e Direitos Especiais. Relatório do Termo de Audiência n ${ }^{\circ}$ PI 80/2000, ref. esclarecimentos sobre o Programa "Jovem Cidadão: Meu Primeiro Trabalho". São Pau1o, 30/08/2000. Mimeografado.

\section{REFERÊNCIAS BIBLIOGRÁFICAS}

BARROS, R.P.; CAMARGO; J.M.; MENDONÇA, R. A estrutura do desemprego no Brasil. Rio de Janeiro: Ipea, 1997. (Texto para Discussão, n.478).

BLANCHFLOWER, D.G.; FREEMAN, R.B. The declining economic status of young workers in OECD countries. In:

(Eds.). Youth employment and joblessness in advanced countries. NBER and University of Chicago Press, 2000.

CAMARGO, J.M. Escolha de Sofia. Revista Exame, São Paulo, p.14, 7 maio 2003. Disponível em:

$<$ http://www.portalexame.abril.com.br/exame $>$.

CARVAlho, S.N. A contribuição dos Programas Jovem Cidadão: Meu Primeiro Trabalho e Bolsa-Trabalho para a discussão das políticas públicas de trabalho e renda e/ou para a juventude. São Paulo: FLACSO, 2002. Mimeografado.

FARIA, V. Políticas públicas e governabilidade: desafios teóricos e práticos. In: FAUSTO, A. (Org.). Desenvolvimento e integração na América Latina e no Caribe: a contribuição das Ciências Sociais. Brasília, DF: Instituto de Pesquisa de Relações Internacionais; Fundação Alexandre de Gusmão; Faculdade Latino-Americana de Ciências Sociais; Ministério da Cultura, 2002. (Edição em homenagem a Vilmar Faria).

FERNANDES, R.; PICCHETTI, P. Uma análise da estrutura do desemprego e da inatividade no Brasil metropolitano. Pesquisa e Planejamento Econômico, Rio de Janeiro, v.29, n.1, p.87$112,1999$.

FISHER, A. The kids are all right. Magazine Fortune, v.143, n.9, p.28, 30 abr. 2001.

FLORI, P.M. Desemprego de jovens: um estudo sobre a dinâmica do mercado de trabalho juvenil brasileiro. Dissertação (Mestrado) - Universidade de São Paulo/Departamento de Econo- 
mia da Faculdade de Economia, Administração e Contabilidade. São Paulo, nov. 2003.

FUNDAÇÃo IBGE. Censo Demográfico 2000. Rio de Janeiro, 2001. (Dados de Educação).

FUNDAÇÃO SEADE. Boletim do Programa Jovem Cidadão: Meu Primeiro Trabalho, São Paulo, n.2, abr.-jun. 2003.

Relatório de avaliação do Programa Jovem Cidadão: Meu Primeiro Trabalho. Pesquisa qualitativa com Monitores do PJC. São Paulo: nov. 2002. Mimeografado.

. Relatório de avaliação do Programa Jovem Cidadão: Meu Primeiro Trabalho. Pesquisa qualitativa com ex-estagiários. São Paulo: jun. 2002. Mimeografado.

JACINTO, C. Nota técnica preparada para o projeto OIT - Governo Argentino (Ministério de Trabajo, Emprego y Seguridad Social). Mesa de Diálogo para la Promoción del Trabajo Decente, 2003.

LEITE, E.M. Projeto USP/CEM/Seade/Cebrap: Desemprego Abordagem institucional e bibliográfica: uma comparação Brasil, França e Japão. Análise qualitativa de grupos de jovens desempregados. São Paulo: fev. 2002 (Relatório Final).

MADEIRA, F.R.; RODRIGUES, E.M. Recado dos jovens: mais qualificação. Jovens acontecendo na trilha das politicas públicas. Brasília, Comissão Nacional de População e Desenvolvimento (CNPD), v.1, p.427-496, 1998.

MADEIRA, F.R. (Comp.). 20 anos no ano 2000: estudos sociodemográficos sobre a juventude paulista. São Paulo: Fundação Seade, 1999. 246 p.
MENEZES-FILHO, N.; PICCHETTI, P. Os determinantes da duração do desemprego em São Paulo. Pesquisa e Planejamento Econômico, Rio de Janeiro, v.30, n.1, p.23-48, abr. 2000.

MINISTÉRIO PÚBLICO DO TRABALHO, Procuradoria Regional do Trabalho, $2^{\text {a }}$ Região, Coordenadoria de Interesses e Direitos Especiais. Relatório do Termo de Audiência $n^{\circ}$ PI 80/ 2000, ref. esclarecimentos sobre o Programa Jovem Cidadão: Meu Primeiro Trabalho. São Paulo, 30 ago. 2000. Mimeografado.

OECD. Organization for Economic Cooperation and Development. Youth unemployment: the causes and consequences. Paris, p.9-46, 1980 .

RODRÍGUEZ, E. Actores estratégicos para el desarrollo. Políticas de juventud para el siglo XXI. SEP - Instituto Mexicano de La Juventud, Centro de Investigación y Estudios sobre Juventud, México, set. 2002. (Colección Jóvenes, n.11).

SEP. Secretaria de Planejamento do Governo do Estado de São Paulo, Convênio Seade-Dieese. PED - Pesquisa de Emprego e Desemprego da Região Metropolitana de São Paulo. São Paulo, jun. 2003.

ZYLBERSTAJN, H. Primeiro emprego e primeiro namoro. Folha de S.Paulo, São Paulo, p.A-3, 29 mar. 2003.

Felícia Reicher Madeira: Socióloga, Demógrafa, Diretora Executiva da Fundação Seade (fmadeira@seade.gov.br). 